\title{
HUBUNGAN ANTARA POSISI MENGEMUDI TERHADAP LOW BACK PAIN PADA SOPIR ANGKOT DI KOTA MALANG
}

\author{
Muhamad Ibrahim Sengadji ${ }^{1}$, Rahayu $^{2}$, Nurkaput $^{3}$ \\ Fakultas Kedokteran Universitas Muhammadiyah Malang, J1. Bendungan Sutami No. 188-A, Kota Malang, \\ 65145, Indonesia, 0341-552443 / 0341551149 \\ Email: emdan_cr7@yahoo.co.id
}

\begin{abstract}
ABSTRAK
HUBUNGAN ANTARA POSISI MENGEMUDI TERHADAP LOW BACK PAIN PADA SOPIR ANGKOT DI KOTA MALANG. Latar Belakang: Posisi mengemudi para sopir angkot dalam waktu berjam-jam dalam posisi duduk tanpa adanya perpindahan menjadi salah satu penyebab terjadinya penyakit seperti nyeri punggung sebagai dampak yang merugikan terhadap tubuh akibat aktivitas tubuh yang salah. Tujuan Penelitian: Mengetahui hubungan antara posisi mengemudi dan nyeri punggung bawah (Low Back Pain) pada sopir angkot yang ada di Terminal Arjosari Kota Malang. Metode Penelitian: Penelitian observasional analitik dengan pendekatan secara cross-sectional, dengan besar sampel sebanyak 93 orang sopir angkot sebagai responden. Analisis data dengan menggunakan statistik uji chi-square dan korelasi spearman dengan $\alpha=0.05$. Hasil dan Diskusi: Menunjukkan bahwa sopir angkot yang ada di Terminal Arjosari Malang yang menjadi responden lebih banyak yang membutuhkan perubahan segera pada posisi mengemudinya (62.4\%), dan banyak yang mengalami nyeri ringan di punggung (63.4\%). Hasil pengujian menunjukkan bahwa antara posisi mengemudi dan nyeri punggung bawah (Low Back Pain) pada sopir angkot yang ada di Terminal Arjosari Kota Malang mempunyai keeratan hubungan yang signifikan (bermakna), dimana terdapat kecenderungan yang jelas bahwa seorang sopir yang posisi mengemudinya tergolong berbahaya, mempunyai resiko yang lebih tinggi mengalami nyeri punggung yang lebih berat, daripada sopir yang membutuhkan perubahan segera pada posisi mengemudinya. Kesimpulan: Terdapat hubungan yang signifikan (bermakna) antara posisi mengemudi dengan nyeri punggung bawah (Low Back Pain) pada sopir angkot yang ada di Terminal Arjosari Kota Malang.
\end{abstract}

Kata Kunci: posisi mengemudi, sopir, Low back pain

ABSTRACT

THE CORRELATION BETWEEN POSITIONS OF DRIVING TO LOW BACK PAIN IN EACH PUBLIC TRANSPORTATION DRIVER IN MALANG CITY. Background: Driving positions while driving for a long without any movement become one of etyology, it called Low Back Pain. Which can damage the position of body caused by the wrong activity. Objective: To find out the corelation between positions of driving and Low Back Pain in each public transportation driver in Arjosari Malang bus station. Methods: This research use analytic observational which applies crossectional approach. It takes 93 sample of public transportation driver as respondent. This research also use chi-squere method and correlation of sperman by $a=0.05$. Results and Discussion: The result of this research shows that $62.4 \%$ needs an immediately to their driving positions and 63,4\% gets Low Back Pain. According to the result above, it is proven that the correlation between positions of driving and Low Back. Pain is very significant. It is quite clear that drivers who driver in wrong position will increase the number of getting Low Back Pain, than the drivers who take movement frequently in their activities, especially in driving. Finally, it is better for the public transportation driver to decrease the risk of Low Back Pain, by take a concern for driving position. Conclusions: There is a significant correlation (significant) between the driving position with low back pain of driver in Arjosari Malang bus station.

Key words: Driving position, Driver, Low Back Pain.

\section{PENDAHULUAN}

Nyeri punggung bawah atau Low Back Pain merupakan keluhan yang sering kita dengar dari orang usia lanjut, namun tidak tertutup kemungkinan dialami oleh orang usia muda (Paliyama, 2003). Low Back Pain atau nyeri punggung bawah merupakan salah satu gangguan musculosceletal yang disebabkan oleh aktivitas tubuh yang kurang baik. Low Back
Pain dapat disebabkan oleh berbagai penyakit musculosceletal, gangguan psikologis dan mobilisasi yang salah (Maher, 2002)

Masalah nyeri punggung bawah yang timbul akibat duduk lama menjadi fenomena yang sering terjadi saat ini. $60 \%$ orang dewasa mengalami nyeri punggung bawah karena masalah duduk yang terjadi pada mereka yang bekerja atau 
yang aktivitasnya lebih banyak dengan duduk. Duduk lama dengan posisi 2 yang salah dapat menyebabkan otot-otot punggung menjadi tegang dan dapat merusak jaringan lunak sekitarnya. Bila keadaan ini berlanjut, akan menyebabkan penekanan pada bantalan syaraf tulang belakang yang mengakibatkan Hernia Nukleus Pulposus (Chang, 2006 dalam Zamma, 2007).

Hasil studi Depkes tentang profil masalah kesehatan di Indonesia tahun 2005 menunjukan bahwa sekitar 40,5 $\%$ penyakit yang diderita pekerja berhubungan dengan pekerjaannya, gangguan kesehatan yang dialami pekerja, menurut studi yang dilakukan terhadap 9.482 pekerja di 12 kabupaten di indonesia, umumnya berupa penyakit musculosceletal (16\%), kardiovasculer (8\%), gangguan syaraf (6\%), gangguan pernafasan (3\%), dan gangguan THT $(1,5 \%)$ (Depkes, 2005). Penelitian kontemporer yang dikemukakan oleh Hu-tech menjelaskan bahwa setidaknya setengah dari pengemudi jarak jauh menderita sakit pada tubuh bagian belakang. Penelitian ini juga menyatakan orang yang mengendarai mobil selama lebih dari 4 jam sehari, 6 kali lebih beresiko absen dari pekerjaannya karena sakit punggung dari pada orang yang mengemudi kurang dari 2 jam (Hutech, 2005).

Diperkirakan kejadian Low Back Pain pada pekerja dapat mempengaruhi produktifitas dan efisiensi kerja, meningkatkan resiko kecelakaan, penyakit akibat kerja, serta target yang telah ditetapkan. Berdasarkan latar belakang ini penulis ingin mengambil judul "Hubungan antara posisi mengemudi terhadap Low Back Pain pada sopir angkot di Kota Malang"

\section{METODE}

Rancangan penelitian yang digunakan adalah observasional analitik dengan pendekatan study cross sectional. Populasi dari penelitian ini adalah seluruh sopir angkot di kota Malang. Kemudian disesuaikan dengan kriteria inklusi yaitu sopir angkot yang ada di Terminal Arjosari Kota Malang dan pengemudi aktif yaitu pengemudi yang mata pencahariannya hanya sopir angkot dan mengemudi sehari lebih dari 4 jam menggunakan metode consecutive sampling. Sopir angkot yang mempunyai penyakit yang menyebabkan Low Back Pain antara lain kelainan tulang punggung (Spine) sejak lahir, penyakit Spondylisthesis, penyakit kissing spine, sacralisasi vertebrae lumbal ke V, Low Back Pain karena trauma, Low Back Pain karena perubahan jaringan, osteoartritis (spondylosis deformans), penyakit fibrositis.

Metode yang digunakan untuk mengukur faktor resiko musculoskeletal disorders pada leher dan tubuh bagian atas adalah dengan metode Rapid Upper Limb Assessment (RULA). RULA menghitung faktor resiko ergonomi pada pekerjaan dimana pekerjaan banyak melakukan pekerjaan dalam posisi duduk atau berdiri tanpa adanya perpindahan. Kemudian tingkatan nyeri pada Low Back Pain diukur dengan skala Quebec antara lain tidak nyeri 0-20, nyeri ringan $21-40 \%$, nyeri sedang $41-60 \%$, nyeri berat $61-80 \%$, nyeri sangat berat 81 100\%. Diketahui dari perhitungan skala Quebec.

Dari hasil kuesioner dengan responden kemudian dianalisis terlebih dahulu, untuk mengetahui posisi pengemudi digunakan RULA, setelah itu dianalisis dengan menghitung rasio prevalensi dengan menggunakan uji korelasi Spearman, sehingga dapat diketahui adanya hubungan antara posisi mengemudi dengan nyeri punggung bawah (Low Back Pain). menggunakan program SPSS.

\section{HASIL DAN PEMBAHASAN}

Penelitian dilakukan terhadap 93 sopir angkot yang ada di Terminal Arjosari Kota Malang. Data diperoleh berdasarkan hasil jawaban kuisioner untuk mengetahui nyeri punggung bawah (Low Back Pain) responden dengan skala Quebec, dan untuk mengetahui posisi mengemudi para sopir angkot tersebut menggunakan RULA

Tabel 1. Distribusi Frekuensi Usia Responden

\begin{tabular}{ccc}
\hline Usia Responden & Frekuensi & Presentase \\
\hline 21-30 tahun & 4 & $4,3 \%$ \\
31-40 tahun & 12 & $12,9 \%$ \\
41-50 tahun & 32 & $34,4 \%$ \\
51-60 tahun & 35 & $37,6 \%$ \\
61-70 tahun & 10 & $10,8 \%$ \\
\hline
\end{tabular}

Tabel 2. Distribusi Frekuensi Kategori Berat Badan Responden

\begin{tabular}{llll}
\hline Kategori Berat Badan & Rata-rata BMI & Frekuensi & Presentase (\%) \\
\hline Sangat Kurus & $15,9 \pm 0$ & 1 & $1,1 \%$ \\
Kurus & $17,25 \pm 0,71$ & 2 & $2,2 \%$ \\
Normal & $22,41 \pm 1,76$ & 54 & $58,1 \%$ \\
Gemuk & $25,89 \pm 0,535$ & 17 & $18,3 \%$ \\
Sangat Gemuk & $30,23 \pm 30,36$ & 19 & $20,4 \%$ \\
\hline & Total & 93 & $100 \%$ \\
\hline
\end{tabular}


Tabel 3. Distribusi Frekuensi Status Gizi Responden

\begin{tabular}{llll}
\hline Kategori Berat Badan & Rata-rata BMI & Frekuensi & Presentase (\%) \\
\hline Gizi Kurang & $16,8 \pm 0,78$ & 3 & $3,2 \%$ \\
Gizi Baik & $22,41 \pm 1,60$ & 54 & $58,1 \%$ \\
Gizi Lebih & $28,18 \pm 3,28$ & 36 & $38,7 \%$ \\
\hline & Total & 93 & $100 \%$ \\
\hline
\end{tabular}

Tabel 4. Distribusi Frekuensi Posisi Pengemudi

\begin{tabular}{lll}
\hline Posisi Pengemudi & Frekuensi & Presentase $(\%)$ \\
\hline Perubahan Segera & 58 & $62,4 \%$ \\
Berbahaya & 35 & $37,6 \%$ \\
\hline Total & 93 & $100 \%$ \\
\hline
\end{tabular}

Tabel 5. Distribusi Frekuensi Hasil Jawaban Kuisioner Skala Quebec

\begin{tabular}{|c|c|c|c|c|c|c|c|c|c|c|c|c|}
\hline \multirow{2}{*}{ Kegiatan } & \multicolumn{2}{|c|}{ Skor 0} & \multicolumn{2}{|c|}{ Skor 1} & \multicolumn{2}{|c|}{ Skor 2} & \multicolumn{2}{|c|}{ Skor 3} & \multicolumn{2}{|c|}{ Skor 4} & \multicolumn{2}{|c|}{ Skor 5} \\
\hline & $\mathrm{F}$ & $\%$ & $\mathrm{~F}$ & $\%$ & $\mathrm{~F}$ & $\%$ & $\mathrm{~F}$ & $\%$ & $\mathrm{~F}$ & $\%$ & $\mathrm{~F}$ & $\%$ \\
\hline $\begin{array}{l}\text { Bangun dari } \\
\text { tempat tidur }\end{array}$ & 2 & 2.6 & 28 & 36.4 & 23 & 29.9 & 20 & 26.0 & 4 & 5.2 & 0 & 0.0 \\
\hline $\begin{array}{l}\text { Tidur nyenyak } \\
\text { sepanjang malam }\end{array}$ & 11 & 14.3 & 28 & 36.4 & 13 & 16.9 & 18 & 23.4 & 7 & 9.1 & 0 & 0.0 \\
\hline $\begin{array}{l}\text { Membalikan } \\
\text { badan ketika tidur }\end{array}$ & 9 & 11.7 & 35 & 45.5 & 21 & 27.3 & 10 & 13.0 & 2 & 2.6 & 0 & 0.0 \\
\hline $\begin{array}{l}\text { Mengendarai } \\
\text { mobil }\end{array}$ & 10 & 13.0 & 31 & 40.3 & 18 & 23.4 & 18 & 23.4 & 0 & 0.0 & 0 & 0.0 \\
\hline $\begin{array}{l}\text { Berdiri selama 20- } \\
30 \text { menit }\end{array}$ & 2 & 2.6 & 34 & 44.2 & 11 & 14.3 & 12 & 15.6 & 13 & 16.9 & 5 & 6.5 \\
\hline $\begin{array}{l}\text { Duduk di kursi } \\
\text { selama beberapa } \\
\text { jam }\end{array}$ & 9 & 11.7 & 31 & 40.3 & 21 & 27.3 & 14 & 18.2 & 2 & 2.6 & 0 & 0.0 \\
\hline Menaiki tangga & 5 & 6.5 & 32 & 41.6 & 19 & 24.7 & 7 & 9.1 & 11 & 14.3 & 3 & 3.9 \\
\hline $\begin{array}{l}\text { Berjalan sejauh } \\
200-400 \mathrm{~m}\end{array}$ & 4 & 5.2 & 37 & 48.1 & 18 & 23.4 & 10 & 13.0 & 8 & 10.4 & 0 & 0.0 \\
\hline $\begin{array}{l}\text { Berjalan beberapa } \\
\text { kilometer }\end{array}$ & 1 & 1.3 & 13 & 16.9 & 16 & 20.8 & 24 & 31.2 & 14 & 18.2 & 9 & 11.7 \\
\hline $\begin{array}{l}\text { Menjangkau rak } \\
\text { tinggi }\end{array}$ & 7 & 9.1 & 40 & 51.9 & 18 & 23.4 & 6 & 7.8 & 4 & 5.2 & 2 & 2.6 \\
\hline Melempar bola & 15 & 19.5 & 44 & 57.1 & 8 & 10.4 & 5 & 6.5 & 2 & 2.6 & 3 & 3.9 \\
\hline Berlari 100 meter & 1 & 1.3 & 15 & 19.5 & 12 & 15.6 & 7 & 9.1 & 22 & 28.6 & 20 & 26.0 \\
\hline $\begin{array}{l}\text { Mengambil } \\
\text { makanan di } \\
\text { kulkas }\end{array}$ & 27 & 35.1 & 41 & 53.2 & 7 & 9.1 & 2 & 2.6 & 0 & 0.0 & 0 & 0.0 \\
\hline $\begin{array}{l}\text { Membereskan } \\
\text { tempat tidur }\end{array}$ & 21 & 27.3 & 50 & 64.9 & 5 & 6.5 & 1 & 1.3 & 0 & 0.0 & 0 & 0.0 \\
\hline $\begin{array}{l}\text { Mengenakan kaos } \\
\text { kaki }\end{array}$ & 24 & 31.2 & 49 & 63.6 & 3 & 3.9 & 1 & 1.3 & 0 & 0.0 & 0 & 0.0 \\
\hline $\begin{array}{l}\text { Membungkuk } \\
\text { untuk } \\
\text { membersikan } \\
\text { kamar mandi }\end{array}$ & 8 & 10.4 & 31 & 40.3 & 9 & 11.7 & 11 & 14.3 & 18 & 23.4 & 0 & 0.0 \\
\hline $\begin{array}{l}\text { Memindahkan } \\
\text { kursi }\end{array}$ & 6 & 7.8 & 44 & 57.1 & 6 & 7.8 & 10 & 13.0 & 10 & 13.0 & 1 & 1.3 \\
\hline $\begin{array}{l}\text { Menarik atau } \\
\text { mendorong pintu } \\
\text { yang berat }\end{array}$ & 5 & 6.5 & 30 & 39.0 & 13 & 16.9 & 7 & 9.1 & 18 & 23.4 & 4 & 5.2 \\
\hline $\begin{array}{l}\text { Membawa } 2 \\
\text { kantong belanja }\end{array}$ & 6 & 7.8 & 34 & 44.2 & 10 & 13.0 & 5 & 6.5 & 10 & 13.0 & 12 & 15.6 \\
\hline $\begin{array}{l}\text { Mengangkat dan } \\
\text { membawa tas } \\
\text { berat }\end{array}$ & 1 & 1.3 & 12 & 15.6 & 21 & 27.3 & 10 & 13.0 & 8 & 10.4 & 25 & 32.5 \\
\hline
\end{tabular}


Tabel 6. Distribusi Frekuensi Nyeri Punggung Bawah dengan skala Quebec

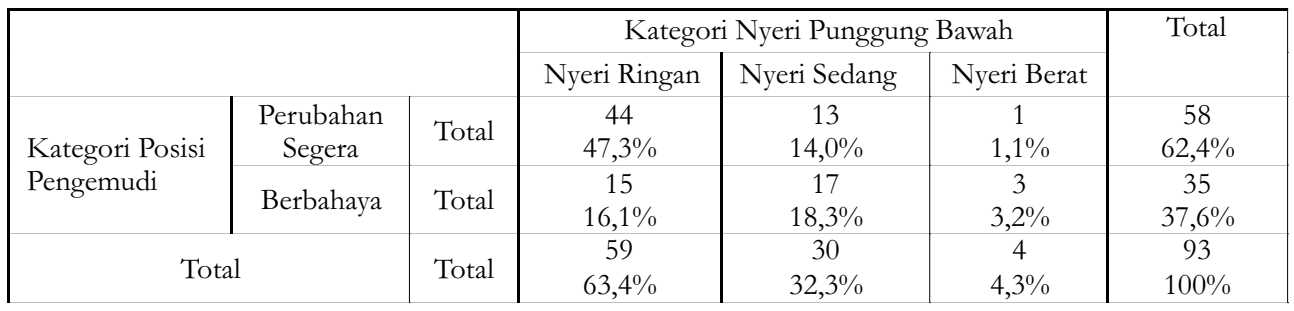

Tabel 7. Tabulasi Silang Antara Posisi mengemudi pada sopir angkot Dan Nyeri Punggung Bawah (Low Back Pain)

\begin{tabular}{lcc}
\hline Hubungan Variabel & Koef. Korelasi & p-value (sig) \\
$\begin{array}{l}\text { Posisi mengemudi } \\
\text { dan nyeri punggung }\end{array}$ & & \\
bawah (Low Back & 0,339 & 0,001 \\
$\begin{array}{l}\text { Pain) pada sopir } \\
\text { angkot }\end{array}$ & &
\end{tabular}

Chi square $=10.757$ dengan signifikansi $(\mathrm{p})=0.005$

Tabel 8. Hasil Uji Korelasi Spearman

\begin{tabular}{lll}
\hline Kategori & Frekuensi & Presentase $(\%)$ \\
Nyeri Ringan & 59 & $63,4 \%$ \\
Nyeri Sedang & 30 & $32,3 \%$ \\
Nyeri Berat & 4 & $4,3 \%$ \\
\hline Total & 93 & $100 \%$ \\
\hline
\end{tabular}

Diperoleh informasi dari tabel 1 bahwa dari 93 orang sopir angkot yang ada di Terminal Arjosari kota Malang dan menjadi responden dalam penelitian ini, lebih banyak yang berusia antara 51-60 tahun yaitu sebanyak 35 orang (37.6\%), $34.4 \%$ berusia antara 41-50 tahun, dan pada sopir lainnya mempunyai rentang usia yang bervariasi.

Berdasarkan hasil penelitian (Tabel 2) diketahui bahwa dari 93 orang sopir angkot yang ada di Terminal Arjosari kota Malang, lebih banyak yang berat badannya tergolong normal dengan rata-rata BMI 22.41 yaitu sebanyak 54 orang (58.1\%), 18.3\% mempunyai berat badan yang tergolong gemuk dengan rata-rata BMI 25.89, 20.4\% mempunyai berat badan yang tergolong sangat gemuk dengan ratarata BMI 30.23, sedangkan pada sopir lainnya mempunyai berat badan yang tergolong kurus $(2.2 \%)$ dengan rata-rata BMI 17.25, dan sangat kurus (1.3\%) dengan rata-rata BMI 15.9.

Diketahui bahwa dari 93 orang sopir angkot yang ada di Terminal Arjosari kota Malang (Tabel 3), lebih banyak yang status gizinya tergolong baikdengan rata-rata BMI 22.41 yaitu sebanyak 54 orang (58.1\%), bahkan 38,7\% mempunyai status gizi yang tergolong lebih dengan rata-rata BMI 28.18, sedangkan pada sopir lainnya mempunyai status gizi yang tergolong kurang (3.2\%) dengan rata-rata BMI 16.

Berdasarkan hasil penelitian (tabel 4) diketahui bahwa dari 93 orang sopir angkot yang ada di Terminal Arjosari kota Malang yang menjadi responden, lebih banyak
51 yang membutuhkan perubahan segera yaitu sebanyak 58 orang (62.4\%), sedangkan $37.6 \%$ responden lainnya justru posisi mengemudinya tergolong berbahaya.

Berdasarkan hasil penelitian pada Tabel 5 diketahui bahwa dari 77 orang responden sopir angkot yang ada di Terminal Arjosari kota Malang, jawaban paling banyak menunjukkan bahwa ada sebanyak $36.4 \%$ sopir yang merasa kesulitan ringan untuk bangun dari tempat tidur, 36.4\% sopir yang merasa kesulitan ringan untuk tidur nyenyak sepanjang malam, $45.5 \%$ sopir yang merasa kesulitan ringan untuk membalikkan badan ketika tidur, $40.3 \%$ sopir yang merasa kesulitan ringan untuk mengendarai mobil, $44.2 \%$ sopir yang merasa kesulitan sedang untuk berdiri selama 20 30 menit, $40.3 \%$ sopir yang merasa kesulitan sedang untuk mengemudi selama beberapa jam, 41.6\% sopir yang merasa kesulitan ringan untuk menaiki tangga, 48.1\% sopir yang merasa kesulitan ringan untuk berjalan sejauh 200-400 meter, $31.2 \%$ sopir yang merasa cukup sulit untuk berjalan beberapa kilometer, $51.9 \%$ sopir yang merasa kesulitan ringan untuk menjangkau rak tinggi, $57.1 \%$ sopir yang merasa kesulitan ringan untuk melempar bola, $28.6 \%$ sopir yang merasa kesulitan sedang untuk berlari 100 meter, 53.2\% sopir yang merasa kesulitan ringan untuk mengambil makanan di kulkas, 64.9\% sopir yang merasa kesulitan ringan untuk membereskan tempat tidur, $63.9 \%$ sopir yang merasa kesulitan ringan untuk mengenakan kaos kaki, 40.3\% sopir 
yang merasa kesulitan ringan untuk membungkuk untuk membersihkan kamar mandi, 57.1\% sopir yang merasa kesulitan ringan untuk memindahkan kursi, 39.0\% sopir yang merasa kesulitan ringan untuk menarik atau mendorong pintu yang berat, $44.2 \%$ sopir yang merasa kesulitan ringan untuk membawa 2 kantong belanja, serta $27.3 \%$ sopir yang merasa cukup kesulitan untuk mengangkat dan membawa tas koper berat. Selanjutnya berdasarkan ke-20 item pertanyaan skala Quebec di atas, dapat diketahui mengenai kategori nyeri punggung bawah (Low Back Pain) pada sopir angkot yang ada di Terminal Arjosari kota Malang secara keseluruhan yang dapat disajikan pada tabel 6 (Skor $0=$ tidak ada kesulitan, Skor $1=$ Kesulitan ringan, Skor $2=$ Kesulitan sedang, Skor $3=$ Cukup sulit, Skor $4=$ Sangat sulit, Skor $5=$ Tidak bisa dikerjakan)

Diketahui bahwa dari 93 orang sopir angkot yang ada di Terminal Arjosari kota Malang (tabel 6) yang menjadi responden, lebih banyak yang mengalami nyeri ringan di punggung yaitu sebanyak 59 orang (63.4\%), 32.3\% mengalami nyeri sedang di punggung, bahkan sebanyak $4.3 \%$ responden lainnya mengalami nyeri berat di punggung.

Pada hasil tabel silang (crosstabs) di atas (tabel 7) terlihat bahwa dari 58 orang sopir angkot yang ada di Terminal Arjosari kota Malang yang membutuhkan perubahan segera pada posisi mengemudinya, ada sebanyak 44 orang yang mengalami nyeri ringan di punggung, 13 orang mengalami nyeri sedang di punggung, sedangkan 1 orang lainnya mengalami nyeri berat di punggung. Adapun dari 35 orang sopir angkot yang ada di Terminal Arjosari kota Malang yang posisi mengemudinya tergolong berbahaya, ada sebanyak 15 orang yang 56 mengalami nyeri ringan di punggung, 17 orang mengalami nyeri sedang di punggung, sedangkan 3 orang lainnya mengalami nyeri berat di punggung. Sehingga dapat dikatakan bahwa terdapat kecenderungan yang jelas dimana seorang sopir yang posisi mengemudinya tergolong berbahaya, mempunyai resiko yang lebih tinggi mengalami nyeri punggung yang lebih berat, dari pada sopir yang membutuhkan perubahan segera pada posisi mengemudinya.

Selanjutnya, untuk menguji adanya hubungan antara posisi mengemudi dan nyeri punggung bawah (Low Back Pain) pada sopir angkot yang ada di Terminal Arjosari kota Malang, maka dapat digunakan uji chi Square (c2) sebagai test independency. Berdasarkan hasil pengujian berdasarkan tabel 7 menunjukkan nilai Chi-Square untuk mengetahui adanya hubungan antara posisi mengemudi dan nyeri punggung bawah (Low Back Pain) pada sopir angkot yang ada di Terminal Arjosari kota Malang sebesar 10.757 yang lebih besar dari c2 tabel dengan $\mathrm{df}=2$, yaitu sebesar 5.991, dengan nilai signifikansi (p) sebesar 0.005 yang lebih kecil dari alpha 0.05. Sehingga dapat disimpulkan bahwa antara posisi mengemudi dan nyeri punggung bawah (Low Back Pain) pada sopir angkot yang ada di Terminal Arjosari kota Malang mempunyai hubungan yang signifikan (bermakna). Selanjutnya, untuk menguji adanya hubungan antara posisi mengemudi dan nyeri punggung bawah (Low Back Pain) pada sopir angkot yang ada di Terminal Arjosari kota Malang, maka digunakan uji korelasi rank spearman.

Berdasarkan hasil pengujian pada Tabel 8 menunjukkan nilai koefisien korelasi rank spearman sebesar 0.339 , dengan nilai signifikansi (p) sebesar 0.001 yang lebih kecil dari alpha
0.05, sehingga tolak Ho, dan dapat disimpulkan bahwa antara posisi mengemudi dan nyeri punggung bawah (Low Back Pain) pada sopir angkot yang ada di Terminal Arjosari kota Malang mempunyai hubungan yang signifikan (bermakna). Dari hasil pengujian menunjukkan arah korelasi yang positif (karena koefisien korelasi bernilai positif), artinya, semakin berbahaya posisi mengemudinya seorang sopir angkot, maka resiko mengalami nyeri punggung yang lebih beratakan cenderung semakin tinggi. Demikian sebaliknya, apabila posisi mengemudi sopir sudah benar, maka resiko mengalami nyeri punggung juga akan cenderung lebih ringan.

Posisi mengemudi adalah posisi dimana seseorang dapat memutar kemudi dengan mudah dan optimal, memantau dan menjangkau instrumen kendaraan, serta meminimalkan potensi cedera bila terjadi kecelakaan yang dapat diukur dengan mengunakan Rapid Upper Limb Assessment (RULA). Rapid Upper Limb Assessment (RULA) merupakan metode yang digunakan untuk mengukur faktor resiko musculosceletal disorders pada leher dan tubuh bagian atas. Rula menghitung faktor resiko ergonomi pada pekerjaan dimana pekerjaan banyak melakukan pekerjaan dalam posisi duduk atau berdiri tanpa adanya perpindahan. Berdasarkan hasil penelitian tentang posisi mengemudi pada sopir angkot yang ada di Terminal Arjosari kota Malang menunjukkan bahwa lebih banyak yang membutuhkan perubahan segera $(62.4 \%)$ yang lebih baik pada posisi mengemudinya. Sebab sopir angkutan umum dalam bekerja tidak terlepas dari posisi duduk, dengan intensitas atau lama waktu yang cukup lama lebih dari 4 jam dalam setiap harinya. Terkadang posisi duduk tidak diperhatikan, sehingga sering merugikan diri sendiri. Posisi duduk yang baik dan benar adalah duduk tegak dengan punggung lurus dan bahu sedikit kebelakang. Tetapi masih banyak yang tidak menyadari akan hal seperti tersebut. Namun hal ini bisa menjadi salah satu penyebab terjadinya penyakit seperti nyeri punggung sebagai dampak yang merugikan terhadap tubuh akibat aktivitas tubuh yang salah (Notoatmodjo, 2007).

Untuk itu, maka penting untuk menambah pengetahuan tentang biomekanika kerja (Occupational Biomechanics) yang mempelajari interaksi fisik antara pekerja dengan peralatan, mesin, dan material sehingga dicapai performansi yang optimal dari pekerja dan meminimalisir resiko terjadinya gangguan musculosceletal (Chaffin, 2003). Selain itu, para pengemudi terutama pada sopir angkot yang mengemudi dalam jangka waktu yang cukup lama dalam sehari, yaitu duduk dengan posisi yang selama berjam-jam sambil menggenggam roda kemudi dan terpajan vibrasi dari kendaraan, penting sekali untuk mengetahui posisi duduk tegak yang baik dengan postur tubuh yang baik saat mengemudi, untuk mengurangi tekanan di discus lumbal. Karena pada kursi yang tegak, pelvis berotasi ke belakang 380 saat duduk dan kurva ke depan di punggung bawah cendurung lurus. Oleh karena itu salah satu cara untuk mengurangi tekanan adalah dengan menggunakan lumbal support, yang akan menjaga lordosis daerah lumbal. Sandaran punggung yang tepat akan mengurangi tekanan di discus lumbal sampai 30\%. Postur duduk sangat berkaitan dengan kondisi punggung manusia, terutama pada kondisi punggung bagian bawah ruas L4 dan L5. Posisi duduk memang memiliki lebih banyak keunggulan jika dibandingkan 
dengan posisi berdiri dalam melakukan pekerjaan. Postur kerja dalam keadaan duduk memiliki keunggulan dibandingkan dengan postur kerja berdiri, postur duduk yang lama dalam sehari, beresiko menyebabkan terjadinya Low Back Pain (Hoggendoorn et al, 2003).

Nyeri punggung bawah (Low Back Pain) adalah nyeri di daerah punggung antara sudut bawah coste (tulang rusuk) sampai lumbosakral. Nyeri juga bisa menjalar ke daerah seperti punggung bagian atas dan panggkal paha (Rachel, 2002). Nyeri punggung bawah merupakan salah satu gangguan musculosceletal yang disebabkan oleh aktivitas tubuh yang kurang baik (Maher, Salmond dan pellino, 2002). Dengan kata lain, Low Back Pain adalah sensasi yang dirasakan penderita dikarenakan penegangan pada otot sekitar leher, bahu, clavicula serta scapula yang terasa menjalar mulai dari atas hingga kebawah punggung, dan akan sembuh dengan sendirinya jika penderita mengistirahatkan tubuhnya selama beberapa jam, yang dapat dihitung dengan mengunakan skala penggukuran nyeri punggung Quebec. Berdasarkan hasil penelitian tentang nyeri punggung bawah (Low Back Pain) pada sopir angkot yang ada di Terminal Arjosari kota Malang menunjukkan lebih banyak yang mengalami nyeri ringan di punggung (63.4\%), 32.3\% mengalami nyeri sedang di punggung, bahkan sebanyak $4.3 \%$ responden lainnya mengalami nyeri berat di punggung. Angka ini menunjukkan bahwa angka kejadian nyeri punggung bawah (Low Back Pain) pada sopir angkot tergolong cukup tinggi. Kejadian nyeri punggung bawah (Low Back Pain) yang dialami oleh sopir angkot yang ada di Terminal Arjosari kota Malang tersebut (Tabel 5), berdasarkan skala nyeri punggung Quebec menyebabkan sebagian besar sopir mengalami beberapa hal berikut, antara lain 39.8\% sopir yang merasa kesulitan ringan untuk bangun dari tempat tidur, 40.9\% sopir yang merasa kesulitan ringan untuk tidur nyenyak sepanjang malam, 51.6\% sopir yang merasa kesulitan ringan untuk membalikkan badan ketika tidur, $46.2 \%$ sopir yang merasa kesulitan ringan untuk mengendarai mobil, 50.5\% sopir yang merasa kesulitan sedang untuk berdiri selama 20-30 menit, $44.1 \%$ sopir yang merasa kesulitan sedang untuk mengemudi selama beberapa jam, $46.2 \%$ sopir yang merasa kesulitan ringan untuk menaiki tangga, 54.8\% sopir yang merasa kesulitan ringan untuk berjalan sejauh 200-400 meter, $26.9 \%$ sopir yang merasa cukup sulit untuk berjalan beberapa kilometer, 58.1\% sopir yang merasa kesulitan ringan untuk menjangkau rak tinggi, 64.5\% sopir yang merasa kesulitan ringan untuk melempar bola, 25.8\% sopir yang merasa kesulitan sedang untuk berlari 100 meter, 60.2\% sopir yang merasa kesulitan ringan untuk mengambil makanan di kulkas, 69.9\% sopir yang merasa kesulitan ringan untuk membereskan tempat tidur, $69.9 \%$ sopir yang merasa kesulitan ringan untuk mengenakan kaos kaki, 46.2\% sopir yang merasa kesulitan ringan untuk membungkuk untuk membersihkan kamar mandi, $60.2 \%$ sopir yang merasa kesulitan ringan untuk memindahkan kursi, 46.2\% sopir yang merasa kesulitan ringan untuk menarik atau mendorong pintu yang berat, $51.6 \%$ sopir yang merasa kesulitan ringan untuk membawa 2 kantong belanja, serta $28.0 \%$ sopir yang merasa cukup kesulitan untuk mengangkat dan membawa tas koper berat. Melalui pengukuran nyeri punggung berdasarkan skala Quebec tersebut, kemudian dapat diketahui lebih jelas mengenai tingkat gangguan musculosceletal yang disebabkan oleh aktivitas tubuh yang kurang baik pada para sopir angkot dengan keluhan nyeri punggung bawah (Low Back Pain) yang mereka rasakan.

Adapun Faktor resiko nyeri punggung meliputi usia, jenis kelamin, berat badan, etnis, merokok, pekerjaan, paparan getaran, angkat beban yang berat yang berulang-ulang, membungkuk, duduk lama, geometri kanal lumbal spinal dan faktor psikososial. Sifat dan kerakteristik nyeri yang dirasakan pada penderita LBP bermacam-macam seperti nyeri terbakar, nyeri tajam, hingga terjadi kelemahan pada tungkai (Idyan, 2008). Nyeri ini terdapat pada daerah lumbal bawah, disertai penjalaran ke daerah-daerah lain, antara lain sakroiliaka, koksigeus, gluteus, ke lateral atau posterior femur, tungkai dan kaki (Bimariotejo, 2009). Namun gejala penyakit punggung yang sering dirasakan adalah nyeri, kaku disertai nyeri, dan paraestesia atau rasa lemah pada tungkai. Gejala serangan pertama sangat penting. Nyeri yang menusuk dan setempat atau terus menerus dan menyebar, adalah gejala yang paling sering dirasakan. Nyeri punggung biasanya terasa sangat nyata dan pada garis tengah punggung, sering meluas sampai ke bagian atas bokong. Anamnesis harus meliputi onset dan lamanya gejala, faktorfaktor yang mendahului, kesehatan umum, riwayat keluarga, lokasi, karakter dan penjalaran nyeri, serta gejala-gejala neurologis seperti kelemahan otot, perubahan sensoris, dan disfungsi usus atau kandung kencing. Oleh karena itu, maka nyeri punggung bawah (Low Back Pain) pada sopir angkot tersebut tidak bisa dianggap remeh, agar tidak mengganggu kesehatan dan kinerja mereka.

Berdasarkan hasil penelitian pada tabel silang menunjukkan bahwa dari 58 orang sopir angkot yang ada di Terminal Arjosari kota Malang yang membutuhkan perubahan segera pada posisi mengemudinya, ada sebanyak 4464 orang yang mengalami nyeri ringan di punggung, 13 orang mengalami nyeri sedang di punggung, sedangkan 1 orang lainnya mengalami nyeri berat di punggung. Adapun dari 35 orang sopir angkot yang ada di Terminal Arjosari kota Malang yang posisi mengemudinya tergolong berbahaya, ada sebanyak 15 orang yang mengalami nyeri ringan di punggung, 17 orang mengalami nyeri sedang di punggung, sedangkan 3 orang lainnya mengalami nyeri berat di punggung.

Hal ini juga didukung oleh hasil pengujian yang menunjukkan bahwa antara posisi mengemudi dan nyeri punggung bawah (Low Back Pain) pada sopir angkot yang ada di Terminal Arjosari kota Malang mempunyai hubungan yang signifikan (bermakna) dengan nilai signifikansi $(p)<0.05$. Hal tersebut ditunjukkan oleh kenyataan dimana dari crosstabs menunjukkan bahwa terdapat kecenderungan yang jelas dimana seorang sopir yang posisi mengemudinya tergolong berbahaya, mempunyai resiko yang lebih tinggi mengalami nyeri punggung yang lebih berat, dari pada sopir yang membutuhkan perubahan segera pada posisi mengemudinya. Hal ini sesuai dengan hasil studi Depkes tentang profil masalah kesehatan di Indonesia tahun 2005 menunjukan bahwa sekitar $40,5 \%$ penyakit yang diderita pekerja berhubungan dengan pekerjaannya, gangguan kesehatan yang dialami pekerja, menurut studi yang dilakukan terhadap 9.482 pekerja di 12 kabupaten di Indonesia, dimana pada umumnya 16\% berupa penyakit musculosceletal (Depkes, 2005). Selain itu, hasil penelitian ini juga sesuai dengan hasil 
penelitian kontemporer yang dikemukakan oleh $\mathrm{Hu}$-tech (2005) yang menjelaskan bahwa setidaknya setengah dari pengemudi jarak jauh menderita sakit pada tubuh bagian belakang. Penelitian ini menyatakan bahwa orang yang mengendarai mobil selama lebih dari 4 jam sehari, 6 kali lebih beresiko absen dari pekerjaannya karena sakit punggung dari pada orang yang mengemudi kurang dari 2 jam.

Banyak penyebab Low Back Pain salah satunya adalah posisi mengemudi yang tidak baik atau statis, dimana beban bertumpu pada tulang belakang yang akan menyebabkan spasme pada otot disekitar punggung memaksa tubuh menjadi condong kedepan secara spontan, dan posisi kepala akan menegakkan, maka otototot punggung akan tertekan dan menegang sebagai kompensasi tubuh maka terjadilah Low Back Pain. Namun hal ini akan terjadi apabila ada penyebab lain yaitu dari faktor pekerjaan dan faktor individu, termasuk pada pada sopir angkot yang sehari-hari harus bekerja dengan duduk untuk mengemudi selama berjamjam sambil menggenggam roda kemudi dan terpajan vibrasi dari kendaraan. Terlebih dalam kegiatan sehari-hari, duduk merupakan kegiatan yang paling sering dilakukan, termasuk sopir angkot yang bekerjanya lebih banyak duduk untuk mengemudikan kendaraannya. Terkadang posisi duduk tidak diperhatikan, sehingga sering merugikan diri sendiri. Posisi duduk yang baik dan benar adalah duduk tegak dengan punggung lurus dan bahu sedikit kebelakang. Tetapi masih banyak yang tidak menyadari akan hal seperti tersebut. Salah satu dampak yang merugikan terhadap tubuh adalah penyakit seperti nyeri punggung (Notoatmodjo, 2007).

Bahkan masalah nyeri punggung bawah yang timbul akibat duduk lama menjadi fenomena yang sering terjadi saat ini. Sebanyak $60 \%$ orang dewasa mengalami nyeri punggung bawah karena masalah duduk yang terjadi pada mereka yang bekerja atau yang aktivitasnya lebih banyak dengan duduk. Duduk lama dengan posisi yang salah dapat menyebabkan otot-otot punggung menjadi tegang dan dapat merusak jaringan lunak sekitarnya. Bila keadaan ini berlanjut, akan menyebabkan penekanan pada bantalan syaraf tulang belakang yang mengakibatkan Hernia Nukleus Pulposus (Chang, 2006 dalam Zamma, 2007).

Jadi, berdasarkan hasil penelitian ini, dapat disimpulkan bahwa antara posisi mengemudi dan nyeri punggung bawah (Low Back Pain) pada sopir angkot yang ada di Terminal Arjosari kota Malang mempunyai keeratan hubungan yang signifikan (bermakna), dimana seorang sopir yang posisi mengemudinya tergolong berbahaya, mempunyai resiko yang lebih tinggi mengalami nyeri punggung yang lebih berat, daripada sopir yang membutuhkan perubahan segera pada posisi mengemudinya. Oleh karena itu, diperlukan perhatian dari masyarakat, terutama pada sopir angkot, untuk lebih memperhatikan posisi mengemudi yang baik untuk mengurangi resiko nyeri punggung bawah (Low Back Pain) akibat terlalu lama duduk untuk mengemudi, mengingat posisi yang salah pada saat mengemudi dapat menyebabkan otot-otot punggung menjadi tegang dan dapat merusak jaringan lunak sekitarnya, sehingga terjadi gangguan musculosceletal yang disebabkan oleh aktivitas tubuh yang kurang baik tersebut.

Dengan mengetahui dan lebih memahami mengenai Low Back Pain yang disebabkan oleh kondisi lingkungan kerja yang tidak nyaman, maka pekerja secara mandiri dapat melakukan upaya-upaya perlindungan terhadap kesehatan kerja dan terhindar dari penyakit akibat kerja, sebagai tindakan pencegahan terhadap Low Back Pain pada pekerja guna meningkatkan kesehatan dan kinerja pekerja

Peneliti menyadari bahwa dalam persiapan dan pelaksanaan penelitian ini masih banyak di jumpai kekurangan dan keterbatasan. Dalam penelitian ini keterbatasan yang di hadapi adalah:

1. Penelitian ini mempunyai keterbatasan alat ukur untuk mengetahui faktorfaktor lain yang dapat menyebabkan terjadinya nyeri punggung bawah (Low Back Pain) pada sopir angkot yang ada di Terminal Arjosari kota Malang, misalnya akibat penyakit musculosceletal, gangguan psikologis dan mobilisasi yang salah, dan faktor-faktor lainnya.

2. Selain itu, penelitian ini hanya melibatkan sopir angkot yang ada di Terminal Arjosari kota Malang untuk mempersempit lapangan penelitian, hal ini dapat menyebabkan keterbatasan aplikasi karena ada kemungkinan penelitian pada lokasi lain akan memberikan hasil yang berbeda disebabkan adanya pengaruh faktor lain. Namun sejauh ini hasil penelitian ini masih menunjukkan hasil yang sesuai dengan penelitian-penelitian lainnya.

3. Peneliti menyadari banyaknya kekurangan pada penelitian ini, sehingga diharapkan untuk peneliti selanjutnya dapat menyempurnakan penelitian ini pada tingkat yang lebih luas dan dapat memberikan hasil yang maksimal.

4. Peneliti mengakui masih banyak kelemahan antara lain peneliti tidak melakukan pemeriksaan Low Back Pain yang disebabkan oleh penyakit lain karena keterbatasan waktu dan biaya.

\section{SIMPULAN}

Simpulan yang didapatkan melalui hasil pengujian menunjukkan bahwa antara posisi mengemudi dan nyeri punggung bawah (Low Back Pain) pada sopir angkot yang ada di Terminal Arjosari kota Malang mempunyai keeratan hubungan yang signifikan (bermakna), dimana terdapat kecenderungan yang jelas bahwa seorang sopir yang posisi mengemudinya tergolong berbahaya, mempunyai resiko yang lebih tinggi mengalami nyeri punggung yang lebih berat, dari pada sopir yang membutuhkan perubahan segera pada posisi mengemudinya.

\section{DAFTAR PUSTAKA}

Bridger, R.S (2003). Introduction to Ergonomics. Singapore: McGraw-Hill Comparison of Methods RULA and REBA for Evaluation of Postural Stress in Odontological.

Bahrudin, Moch. 2011. Pemeriksaan Klinis di bidang penyakit syaraf klinik neurologi dan neurobehavariori fungsi luhur, Malang: umm press.

Bahrudin, Moch. 2013. Neurologi Klinis. Malang: umm press. 
Bimariotejo. 2009. Low Back Pain (LBP). Diakses tanggal 15 Januari 2013 dari http://bimariotejo.wordpress.com/ 2009/2007/07/07/low-back-pain-lpb/

Canadian Centre of Occupational Health and Safety. 2005. Work Related Muskuloskeletal Disorders. January 22, http:/www.ccohs.ca

Chaffin, D. Andersson, G.B.J., Martin. 2003. Occupational Biomechanics. New York : John Wiley \& Sons, Inc.

Departemen Kesehatan Republik Indonesia. (2005).Profil Kesehatan Indonesia 2005. http://www.depkes.go.id

Grandjean, E, 1993, Fitting the Task to the Man, 4th ed, Taylor \& Francis Inc, London

Harsono. 2009. Kapita Selekta Neurologi. Cetakan Ke-empat. Gajah Mada University Perss. Yogyakarta.

Holdcroft, Anita, 2005. Core Topic in Pain. Cambridge University Press. (Diunduh 21 Februari 2014.

HSC, Health and Safety Statistic 2006/2007. [cited 2008 juni 2007]. http://www.hse.gov.uk/statistics

Idyan, Z. (2008). Hubungan Lama duduk Saat Perkuliahan dengan Keluhan Low Back Pain. Diambil 2 Februari 2013 dari http://inna-ppni.or.id.

Judith A, Kaufmann (2000), Low Back Pain Diagnosis and Management in Primary care. Dalam Lippncott's Primary Care Practice, Vol 3. Number 4, Philadelphia: Lippincott William \& William Inc.

Keith L. Moore, Anne M.R. Agur. 1996. Anatomi Klinis Dasar. Jakarta : Hipokrates

La Dou, Joseph.2007. Occupational Health and Safety 2nd edition. National Safety Council.

Maher, Salmond \& Pellino. 2002. Low Back Pain Syndroma. Philadelpia: FA Davis Company.

Nursalam, 2002. Pendekatan Praktis Metodelogi Riset Keperawatan. Cetakan Kedua. CV Infomedika: Jakarta.

Notoatmodjo, S. 2007. Promosi Kesehatan dan Ilmu Perilaku. Jakarta : Rineka Cipta

Oborne, David J. 1995. Ergonomic at Work Third Edition. England: Jhon Wiley and Sons Ltd.

Paliyama, J.M., 2003, Perbandingan Efek Terapi Arus Interferensi dengan TENS dalam Pengurangan Nyeri Punggung Bawah Muskuloskeletal, Fakultas Kedokteran Diponegoro, Semarang.

Pengel LHM, Herbert RD, Maher CG, Refshauge KM. Acute low back pain: systematic review of its prognosis. BMJ 2003; 327: 323..

Porter, J.M and Gyi, D.E. 2002. The Prevalence of Musculoskeletal Troubles Among Car Drivers. Oxford Journal Occupational Medicine 52:4-12

Richard S Snell, MD, PhD. 2000. Anatomi Klinik untuk Mahasiswa Kedokteran Edisi 6. Jakarta: EGC

Rachel. Sulvana. (2005). Nyeri Pnggung Bawah Pekerja Perawatan Lapangan Golf di Perusahan X dan faktor -faktor yang berhubungan. Tesis. Jakarta: Fakultas Kedokteran Universitas Indonesia.

Soeharso. (2006). Pengantar Ilmu Bedah Orthopedi. Yogyakarta: Yayasan Essentia Medica.

Shocker, M. (2008). Pengaruh Stimulus Kutaneus: SlowStroke Back Massage terhadap Intensitas Nyeri Osteoarthritis. Diambil 2 Februari 2013 dari http:// www.clinicalevidence.

Stanton, Neville, el al. 2005. Handbook of buman Factors and Ergonomic Methods. USA: CRC Press.
Tarwaka, Solichul H.A. Bakri, Lilik Sudiajen. 2004. Ergonomi untuk keselamatan, Kesehatan kerja dan Produktivitas. UNIBA PRESS.

Wikipedia. 2012. Mengemudi [online]. (Diunduh 19 Desember 2012). Tersedia dari: http://id.wikipedia.org/ wiki/Mengemudi

Widayat, 2004. Metode Penelitian Pemasaran. Edisi Pertama, cetakan I, Penerbit Universitas Muhammadiyah Malang. 